Feature Article

\title{
Grain Size and Chemical Composition of Sediments to Determine the Governing Geochemical Processes in Fluvial Environments
}

\author{
Sansfica M. Young \\ Department of Environmental Technology, Faculty of Technology, University of Colombo, Colombo 03,
} Sri Lanka

\begin{abstract}
The environmental impact on the river system and the bay or a tidal flat area is of significance since these environments act as sinks of pollutants. The river system gradually gathers the material that flows along the river and settles it at the downstream area. The geochemistry of sediments of the rivers and the Bay or tidal area are signatures of the mass transfer process that occur in fluvial environments. Thus, the processes such as provenance, maturity of sediments, weathering, climatic implications, sedimentary processes, heavy mineral concentrations, sorting and mixing effect, grain size variation, transport and downstream accumulation and effect of tributaries can be determined using geochemistry. The major oxides and trace element concentration of the sediments of the river and the Bay or Tidal area is thus very important to determine the fluvial processes. Comparison of two different fluvial environments with different climatic conditions and geology where one consists of the river with a Bay in Sri Lanka and the other consisting of a river with a tidal flat in Japan is thus conceded. The environmental assessment using elements of sediments in such environments have been effective due to the possibility of being able to identify the fluvial processes that are affected by the river and Bay or tidal sediments in two different systems.
\end{abstract}

Keywords: Fluvial environment, geochemistry, sediment, major oxides, trace elements

\section{Introduction}

Stream sediments comprise of the compounds of the lithologies present in their drainage basins, and therefore, facilitate in a mechanism for mapping regional geochemical characteristics of their source terranes (Ottesen and Theobald, 1994). However, the compositions of clastic sediments are different from that of their source rocks due to the effect of a combination of numerous interacting factors that function between source and sediment. The factors include hydrodynamic sorting, weathering, heavy alluvial storage, mineral concentration and many others Johnsson (1993).

The significance of Kuma River and Yatsushiro Bay in Japan is that, they are situated in the island of Kyushu, which is of Japanese Island arc, and is the largest river subjected to Asian monsoons, flooding occur with high rain fall while a large population depend on the river for their living. The first ever dam removal occurred in Arase, Japan which was situated in the middle region of the Kuma River. The river mouth is at Yatsushiro, which comprises of a tidal flat subjected to almost $1 \mathrm{~m}$ tidal variation. On the other hand, the Mahaweli River rises on the Hatton plateau of the wet zone, flows north through the Intermediate zone, flows past Polonnaruwa to its mouth in Koddiyar Bay, $11 \mathrm{~km}$ south of Trincomalee in the dry zone (Figure 1). Mahaweli River flows throughout the year, providing water for agriculture in the eastern dry zone. The Mahaweli River mainly flows through the Highland complex (Figure 1).

*Correspondence: sansfica@et.cmb.ac.lk

Tel: 0719099122

ISSN 2235-9370 Print / ISSN 2235-9362 Online (C University of Sri Jayewardenepura 
It was thus important to select these locations to identify the processes in (a) Mahaweli River and Trincomalee Bay system and (b) Kuma River and Yatsushiro Bay system to study the geochemical impacts as a whole system of River, estuarine and Marine environments in two different environmental, geological and climatological aspects.
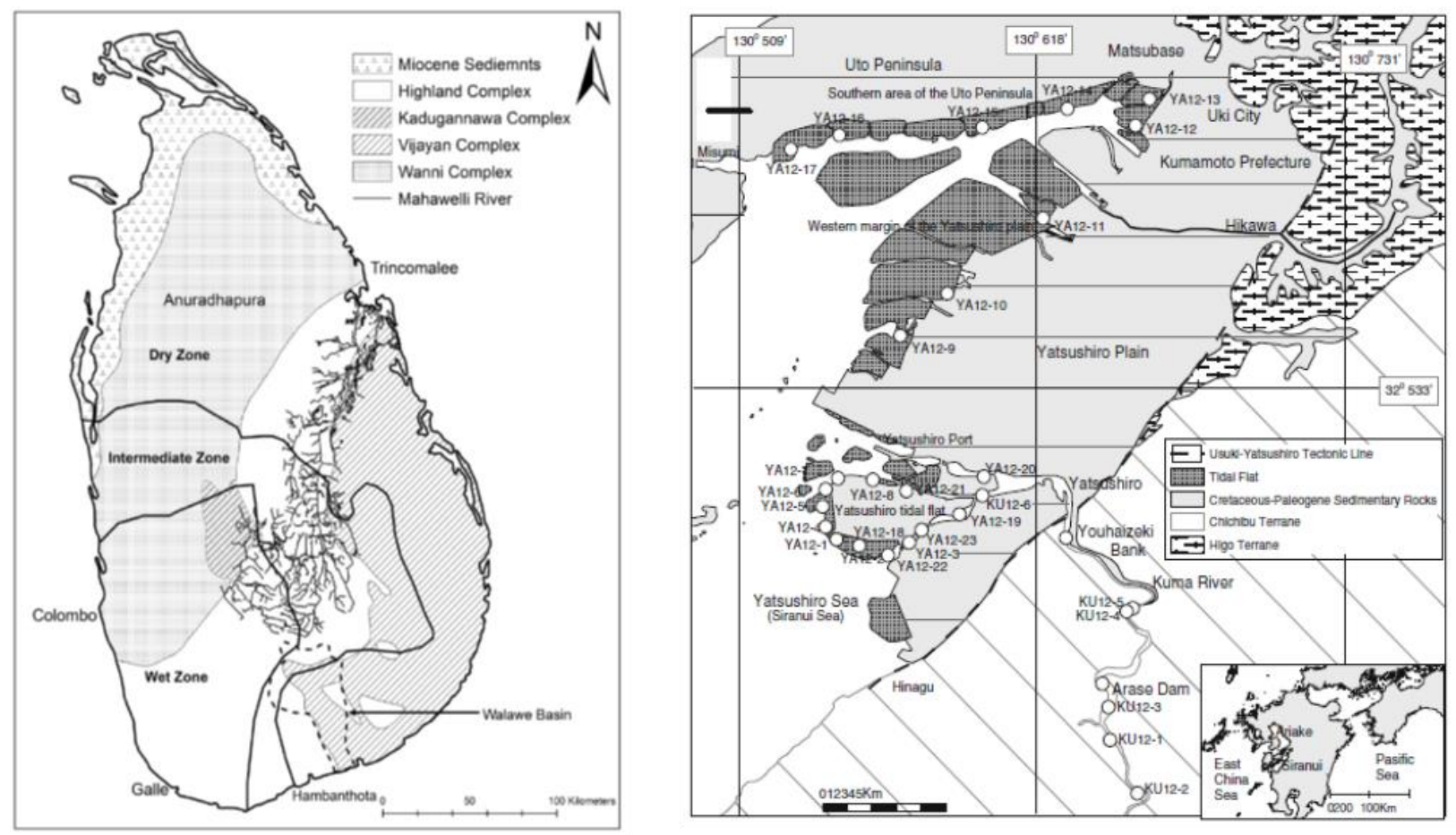

Figure 1. (a) The geology of the Mahaweli River and Trincomalee Bay (b) Kuma River and the sampling locations in Kumamoto prefecture, Kyushu Island, Japan.

The Kuma River in Japan consisted of a dam which was partially opened during the time of sampling which was located $19.9 \mathrm{~km}$ from the mouth of the $115 \mathrm{~km}$ long Kuma River (Figure 1). The drainage area of the Kuma River is $1,880 \mathrm{~km}^{2}$, and it is considered to be one of the three most rapid rivers of Japan. The Kuma River falls to the Yatsushiro Bay a semi-closed estuary opening to the East China Sea. The Kuma River and the Yathsushiro Bay area is subjected to all four climatic conditions.

The geology of Kuma River and the Yathsushiro Bay area is highly complex. The Kuma River flows through the Chichibu terrane, the Hisatu volcanics, the Cretaceous-Paleogene sedimentary rocks, the Shimanto terrane, and associated alluvial deposits (Figure 1). Yatsushiro Bay is located in the Chichibu terrane (Figure 2). The Yatsushiro area is within the inner and outer zones of the Kyushu Cretaceous system (Sakai et al., 1992). The sedimentary basins of Kyushu belong to the Cretaceous and Tertiary periods.

The Yatsushiro region and the Kuma River catchment intersect the Early Cretaceous shallowmarine and turbidite basins and the Late Cretaceous non-marine, shallow-marine, and turbidite basins in the Ryoke terrane (Sakai et al., 1992). The Kawabe River joins the Kuma River after it flows through the Shimanto terrane and the Chichibu terrane (Figure 1). Kyushu has active island arc type volcanoes, active faults, and significant crustal movement (Ogawa et al., 1992).

Thus, the objectives of investigating the Mahaweli River sediments would be to identify the provenance and the processes controlling these systems for future development (construction), natural hazards and environmental issues. Assessment of the Mahaweli River sediments would make known the 
geochemical characteristics of sediments in the Mahaweli River, in order to understand the intensity of weathering and erosion and to identify the provenance signatures.

The intention of investigating the Trincomalee Bay surface sediments is to establish the geochemical characteristics of surface sediments in the three sectors of Trincomalee Bay in order to determine their provenance, evaluate roles of circulation and oceanic influence, within the Bay in modifying sediment compositions and assess present environmental conditions. The objective of studying the Kuma River and Yatsushiro Bay is to identify the effect of Kuma River sediments on Yatsushiro Bay after opening of the Arase dam gates 2010 April, and document the geoenvironmental conditions of Yatsushiro Bay and the Kuma River.

\section{Geochemical implications of fluvial systems}

In environmental studies the sampling procedure and sampling locations are very important. It is generally accepted that systematic sampling gives a better representation regarding the samples collected for geochemical interpretations. However, in most of the cases, especially in fluvial, Bay and tidal environments sampling is difficult. The sampling deals with deep and shallow water bodies, deep and shallow mud flats, steep banks, eroded land forms, shrubs or forest cover and therefore, the sampling locations has limited or no access for sampling. Therefore, systematic sampling is challenging in such studies. Thus, leading to random sampling methods from where easy access is available for sampling.

Sample preparation is critical since the samples are most of the time collected as wet samples since they are submerged under water. Due to storage of samples that are wet, oxidation reactions could take place. However, in most cases the total elemental concentrations of the soil or sediment is not subjected to change. Transporting and storing the samples in sealed and cool conditions is important. If not microbial reactions could take place and change the oxidized or reduced conditions leading to change in fractions of functional groups.

XRF analysis is a widely used very accurate method to detect the major oxides and trace element concentrations of bulk soil and sediment samples. The elemental concentrations and its variation is widely used to determine the source composition, climatic variation, heavy mineral signatures, effect of tributaries, natural activities and mainly pollution interpretations due to anthropogenic activities.

The elemental concentration of soil and sediment used to determine its composition is usually normalised with Upper Continental Crust (UCC, Taylor and McLennan, 1985) for soils and with Post Archean Australian Shale (PAAS) for sediments. The variation is interpreted using enrichments or depletions of elemental concentrations on an average basis. This method of interpretation will give an idea about the elements that show different signatures based on environmental concerns ( $\mathrm{As}, \mathrm{Pb}, \mathrm{Zn}, \mathrm{Cu}, \mathrm{Ni}$, Cr, Young and Ishiga, 2014a, b), Provenance indicators (Th, Sc, Zr, Cr, V, Y, Ni, Roser and Korsch, 1999), heavy mineral signatures ( $\mathrm{Zr}, \mathrm{Th}, \mathrm{Nb}, \mathrm{Y}, \mathrm{Sr}, \mathrm{Ti}$, Roser et al., 2000), weathering activities (Na, K, $\mathrm{Al}, \mathrm{Si}, \mathrm{Mg}, \mathrm{Fe}$, Price and Velbel, 2003), petrogenic signatures (P) and progressive weathering of calcareous detritus (Ca, Sr, Young et al., 2013). Further, statistical methods involving cluster analysis, Principal Component Analysis (PCA) and factor analysis (Woods et al., 2013) is used to interpret the elemental variation for natural as well as anthropogenic activities (Young et al., 2014; Young et al., 2013). These principles could group or cluster the elements that relate to one or a few geochemical process so that it could be understood as to how it took place and the consequences of it to the environment.

Further, there are number of indexes developed by many researchers. Such as; geo-accumulation index, as for the guidelines used by NYSDEC (New York State Department of Environmental Conservation) values of lower effect level (LEL) and severe effect level (SEL), ISQG (Interim Sediment 
Quality Guidelines) and probable effect level (PEL) is generally used to evaluate sediments (Young et al., 2014).

There are single indices which are indicators used to calculate contamination of only one metal, which include contamination factor, ecological risk factor, enrichment factor and index of geoaccumulation (Qingjie et al., 2008). Weathering can be determined using various methods. However, most of the commonly used weathering indices such as CIA (Nesbitt and Young, 1982; Price and Velbel, 2003), PIA (Fedo et al., 1995), CIW (Harnois, 1988), and WIP (Ohta and Arai, 2007) include CaO in the calculations. Each of the index is used for different purposes where the applications are based mainly for assessment of pollution and weathering. The intensity of pollution is mainly in relation with heavy metals and are evaluated based on sediments of different environments such as marine, brackish, lake and fluvial (Ishiga et al., 2012; Young et al., 2014; Young and Ishiga, 2014a,b).

The Enrichment Factor (EF) is another index calculated using the formula given in Zhang et al., (2007) where $(\mathrm{Me} / \mathrm{Fe})_{\text {Sample }}$ is divided by $(\mathrm{Me} / \mathrm{Fe})_{\text {Background }}(\mathrm{Me}$, metal) and used where the values of 0.51.5 suggest that the trace metals concerned may be derived entirely from crustal materials or natural weathering processes (Zhang and Liu, 2002). Values greater than 1.5 suggest that a significant portion of the trace metal has been delivered from non-natural (anthropogenic) sources (Zhang et al., 2007).

In addition, the Loss on Ignition (LOI) is also commonly used to discuss the loss on organic matter content upon burning in a muffle furnace to $105^{\circ} \mathrm{C}$ for two hours which is an indication of the organic matter content on soils and sediments. The higher the organic matter content not only the nutrient content will be high, the heavy metal content also will increase since the absorption, adsorption and coagulation takes place very easily into organic matter.

The downstream variation of sediments can be related with the accumulation and variation of the elemental concentrations. Along a stream the sediments are subjected to mechanical, chemical and physical weathering. The slow and fast flow of water, the water and sediments entering the main stream in confluences, the climatic variation, the anthropogenic inputs and erosion are factors that cause to change the elemental variation of sediments along the stream.

Heavy minerals are a major component in sediments and soil since they are products of weathering process. Fluvial sediments of a river are resulted from weathering of a variety of parent rocks that are within the river basin. The composition of heavy minerals are mainly controlled by several environmental processes, including selective physical breakdown, hydrodynamic sorting, and chemical weathering during transport and deposition. The geomorphologic evolution and the fingerprint of an area's geological setting can be provided by using tracing studies for river sediments (Roser and Korsch, 1999). The heavy mineral signatures are determined mainly by the elements $\mathrm{Zr}, \mathrm{Ti}, \mathrm{Cr}, \mathrm{V}, \mathrm{Y}, \mathrm{Ni}$, Th and Sc (Roser et al., 2000). Heavy minerals do not travel very far unless with heavy currents since the soils and sediment grains are heavy. However, mineral such as mica will travel very far and mainly deposit downstream and close to and within the river mouth area. Due to the effect of currents, high energy areas are formed and the sediments consisting with heavy minerals are deposited in these places with high energy. Therefore, the heavy minerals that are brought downstream along the river are deposited in patches consisting of heavy energy within the Bay area. The entire river transporting sediments will cut across one or many climatic zones where the sediments are subjected to different climatic conditions. Thereby the sediments undergo chemical changes due to the different chemical environments.

\section{Grain size variation of river systems in Sri Lanka and Japan}

Different size factions used for grain size analysis and for chemical composition differ based on the purpose of the study and the river morphological features. Thus, the grain size analysis of the Kuma River and Yatsushiro Bay sediments were sieve separated into fine $(0.075-0.25 \mathrm{~mm})$ and medium $(0.25-$ 
$0.85 \mathrm{~mm})$ size fractions $(\mathrm{n}=14)$. The samples were oven dried and treated with $30 \% \mathrm{H}_{2} \mathrm{O}_{2}$ for at least $24 \mathrm{~h}$ prior to measurement. Grain size analysis for six size fractions was carried out at Tokyo University of Science for the surface and bottom sediments using a SALD 3,000 grain size analyser. Calculations of grain size and sorting were made following Folk and Ward (1957). The Mahaweli River sediment samples were first hand-sieved to remove the small amount of material $>2,000 \mu \mathrm{m}$. The $<2,000 \mu \mathrm{m}$ fraction was then split to provide a sample for bulk sediment analysis $(<2,000 \mu \mathrm{m})$. A second split was then sieved to separate $<180 \mu \mathrm{m}$ and $180-2,000 \mu \mathrm{m}$ fractions for fractional analysis.

The grain size variation along a river is a major indication of the geochemical processes that affect and control the river sediment. In general, sediment grain size in rivers decreases downstream (Parker, 1991; Surian, 2002) but this is not the case for the Mahaweli River. The main channel sediments were coarse to medium sand with lesser clay fractions, except for eleven samples in the middle reaches that contained more than $20 \%$ clay (Figure 2 ). The gravel content of most samples was low $(<20 \%)$, except for one sample in the middle reaches and two in the lower reaches. There is little improvement in sorting along most of the main channel, and median grain size is also highly variable. This is probably due to the number of tributaries entering the main channel, even in the middle reaches. The sediments only become well sorted in the lowermost reaches of the river, where tributaries are fewer. Mean grain size of the Trincomalee Bay sediments ranged from -0.13 to $4.60 \phi$ equivalent to very coarse sand to coarse silt. Sediments are also generally well sorted.

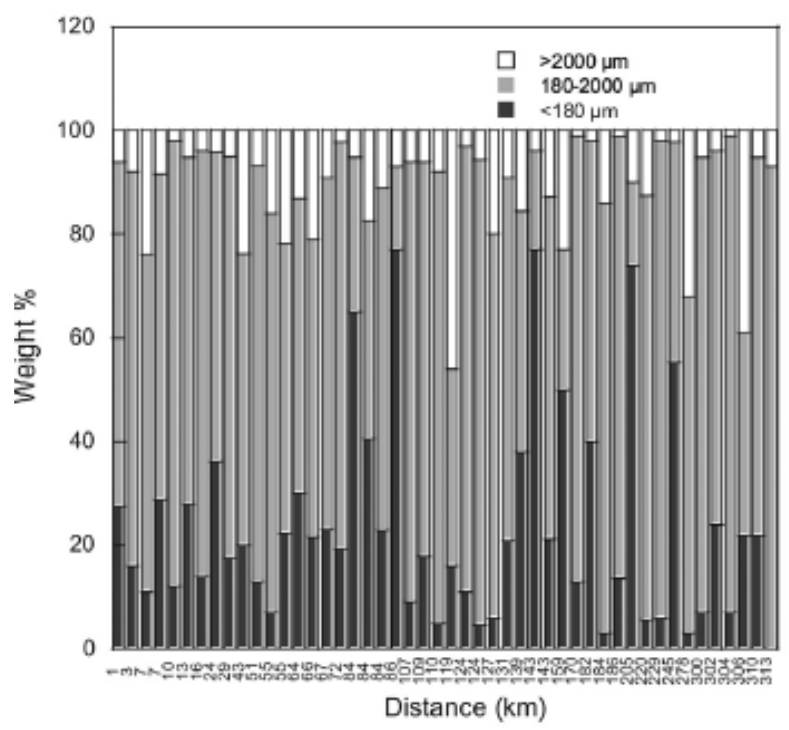

Figure 2. Variation in stream sediment size fractions along the Mahaweli River.

The Kuma River sediment sampling was carried out for surface and bottom sediment to determine if there is a difference in grain size and its chemical variation due to removal of the Arase dam. The median grain size (Md ф) of the surface sediments (-0.57 and 3.27 ф) is poorly sorted and has a wider range while the bottom sediments (-0.93 and 2.93 ф) are moderately sorted and is within a shorter range. The surface and bottom sediments of the Kuma River and the Yatsushiro Bay mainly consist of very coarse sand to very fine sand (Figure 3). Thus, there is a clear difference in the surface and bottom sediments. 

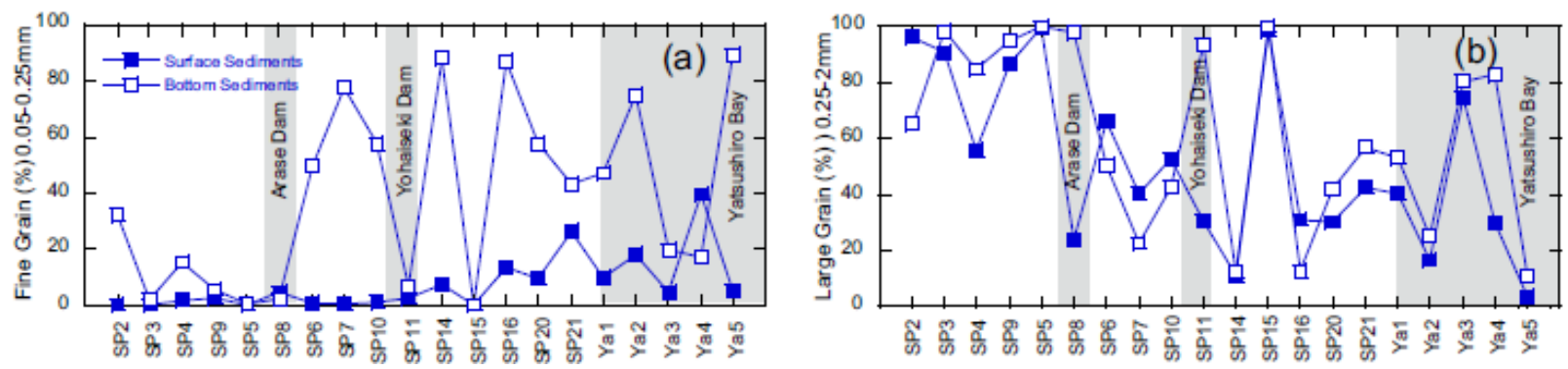

Figure 3. Grain size variation of the (a) fine $(0.25-0.005 \mathrm{~mm})$ and (b) medium $(0.25-2 \mathrm{~mm})$ fractions of surface and bottom sediments of Kuma River and Yathsushiro Bay.

When consider the Arase dam area median grain sizes $(\Phi)$ for the bottom sediment are low (-0.93, $-0.83)$ however is high in the dam surface sediments $(2.63,2.53)$. This implies that in the dam sediments fine fraction is very less and with higher coarse sand grain percentages at the dams. It is very clearly seen that above the Arase Dam (upstream) median grain size of the river sediments is low in both surface and bottom sediments. The surface sediment grain size of the river is higher than that of the bottom sediments. The sorting is low (average, 1.0) in the bottom sediments but high (average, 1.1) in the surface sediments. Most of the bed load sediments were transported downstream and also point bars were formed in the banks of the river. The grain size analysis of the Arase Dam and the Kuma River sediment clearly shows that, the channel morphology and the hydraulics is influenced by the grain size of river bed sediments (Surian, 2002).

\section{Chemical variation of river systems in Sri Lanka and Japan}

The XRF method of analysing the elemental concentrations of bulk sediments, rock and soils is a powerful, well-established and a widespread practice. Therefore, to determine the elemental concentrations of the sediments for the Mahaweli River, Trincomalee Bay and Kuma River, Yatsushiro Bay systems, the XRF method was used.

The chemical composition of the sediments was determined by XRF analysis to carry out the interpretations. Approximately $50 \mathrm{~g}$ of each sample were oven dried at $160^{\circ} \mathrm{C}$ for $48 \mathrm{hrs}$ before crushing in a tungsten carbide ring mill. Portions (7-10 g) of the crushed materials were transferred to glass vials and dried at $110^{\circ} \mathrm{C}$ for $24 \mathrm{~h}$ prior to determination of loss on ignition (LOI). The LOI values were calculated from the net weight loss after ignition in a muffle furnace at $1020^{\circ} \mathrm{C}$ for more than $2 \mathrm{~h}$. Abundances of 23 major elements and trace elements (As, Pb, Zn, Cu, Ni, Cr, V, Sr, Y, Nb, Zr, Th, Sc, TS, F, Br, I, Cl, Ti, Fe, Mn, Ca, and P) were determined from pressed powder briquettes, following Ogasawara (1987) using a Rigaku RIX-2,000 XRF spectrometer.

Analytical methods, instrumental conditions, and calibration followed those described by Ogasawara (1987). The pressed powder analysis followed Ogasawara (1987), using conventional peak over background (Ip/Ib) method, with calibration against recommended or preferred values for seven Geological Survey Japan (GSJ) rock standards. Arsenic values were also corrected for Pb peak overlap. Average 2-sigma coefficients of variation for the three elements range from 3.5-6.7\% relative at concentrations of $>5 \mathrm{ppm}$. This was confirmed by repeat analysis $(n=5)$ of seven samples from this study, yielding similar results.

To compare with typical upper crustal values and determine the differences between the sample types the average values in the sediments of the Mahaweli River, rocks and soils of the catchment area were normalised against average Post Archean Australian shale (PAAS; Taylor and McLennan, 1985). The Mahaweli River sediments are highly enriched in $\mathrm{CaO}, \mathrm{V}$ and $\mathrm{Zr}$, and moderately enriched in $\mathrm{TiO}_{2}$, $\mathrm{Cr}, \mathrm{Sr}, \mathrm{Nb}$, Th and $\mathrm{Sc}$ while $\mathrm{Cu}$ and $\mathrm{Ni}$ are depleted relative to PAAS (Figure 4a). Most elements in the 
soils are depleted (e.g. $\mathrm{Zn}, \mathrm{Cu}, \mathrm{Ni}, \mathrm{Y}$ and $\mathrm{Nb}$ ). The rocks are also mostly depleted relative to PAAS, especially for $\mathrm{TiO}_{2}, \mathrm{Cu}, \mathrm{Ni}, \mathrm{Nb}, \mathrm{Zr}$ and $\mathrm{Th}$ (Young et al., 2013). The sediments are slightly enriched in
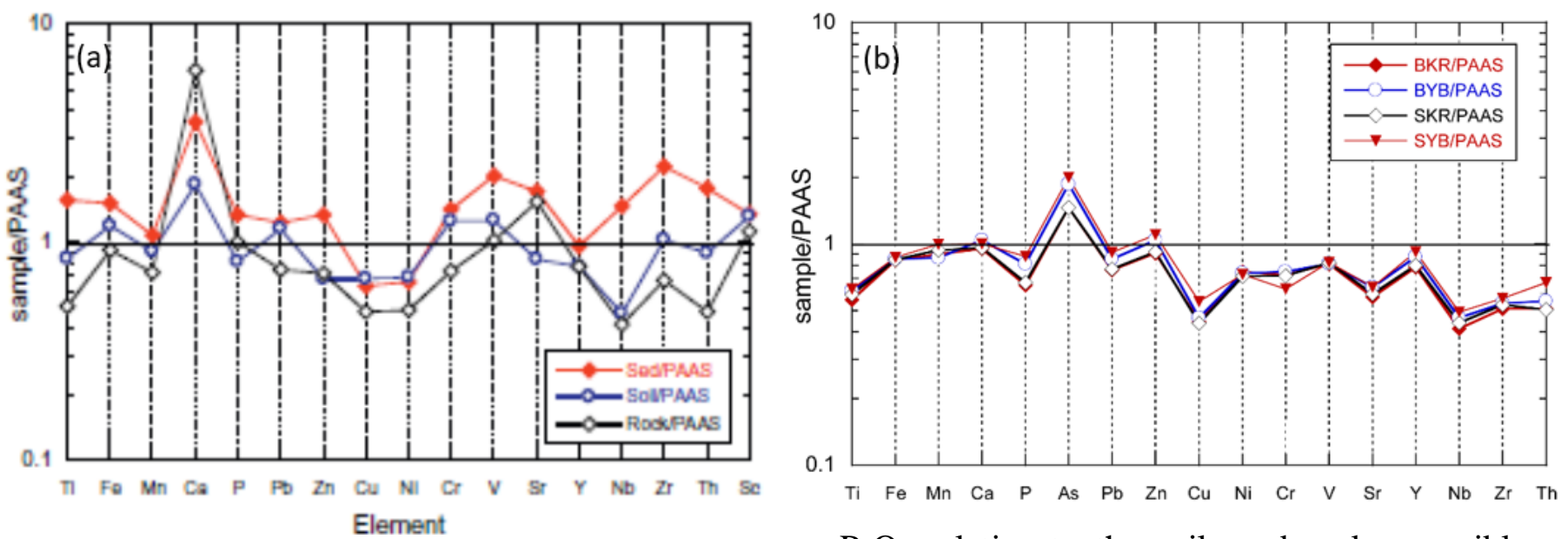

$\mathrm{P}_{2} \mathrm{O}_{5}$ relative to the soils and rocks, possibly due to concentration of accessory phases such as apatite and monazite (Nagarajan et al., 2007).

Figure 4. (a) PAAS-normalized averages for the sediments, soils and basement rocks of the Mahaweli River, (b) PAAS-normalized averages for the Bottom Kuma River (BKR) Bottom Yatsushiro Bay (BYB), Surface Kuma River (SKR) and Surface Yatsushiro Bay (SYB) sediments. Taylor and McLennan (1985).

All four sampling types for Bottom Kuma River (BKR) Bottom Yatsushiro Bay (BYB), Surface Kuma River (SKR) and Surface Yatsushiro Bay (SYB) sediments show a similar variation for all the elements. Thus, except for Arsenic all other elements Ti, Fe, Mn, Ca, P, Pb, Cu, Ni, Cr, V, Sr, Y, Nb, Zr and Th are depleted in relation to PAAS (Figure 4b). Acquiring the similar average composition in all four types of samples relation to PAAS indicated that the sediments are not undergoing major geochemical changes with the different fluvial environments. However, when consider each element variation along the river there are differences in the surface as well as in the bottom sediments and also before and after the Arase dam (Young and Ishiga, 2014b).

\section{Provenance signatures of river systems in Sri Lanka and Japan}

Possibility of provenance, sorting or accumulation of heavy minerals can be evaluated using $\mathrm{Th} / \mathrm{Sc}$ and $\mathrm{Zr} / \mathrm{Sc}$ where the ratio serves as a proxy for identifying heavy mineral concentrations, because it is highly sensitive to accumulation of zircon (McLennan et al., 1993). In the Mahaweli River the sediments are highly scattered and shows that they are slightly enriched in zircon, the basement rocks show a range from mafic through to felsic compositions, as do the soils (Figure 5a). The basement samples plotting at higher ratios include quartzites and quartzofeldspathic gneisses. The Trincomalee Bay sediments indicates that the bulk of the clastic sediment in Trincomalee Bay is derived from the Mahaweli River. The higher $\mathrm{Zr} / \mathrm{Sc}$ ratios in Koddiyar Bay near the Mahaweli delta, and lowest values in the most distal setting of the Inner Harbour suggest that heavy minerals have played an important role in elemental distributions within Trincomalee Bay (Figure 5a). 

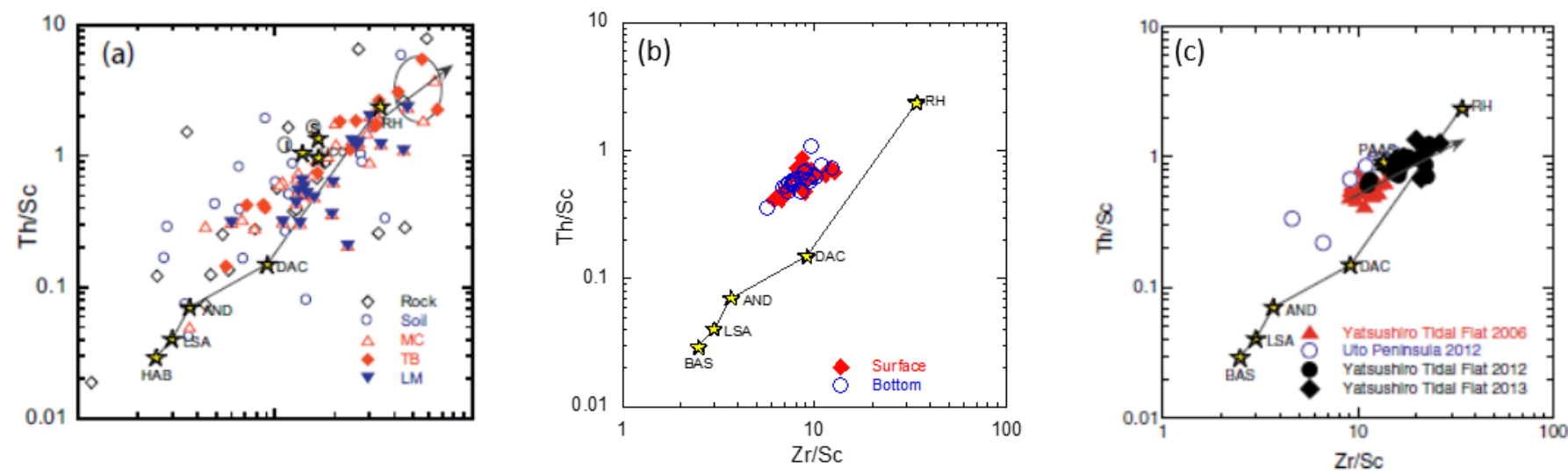

Figure 5. Zr/Sc-Th/Sc (McLennan et al., 1993) for the (a) Mahaweli River and Trincomalee Bay (b) Kuma River and (c) Yatsushiro Bay (MC-Main Chanel, TB-Tributary, LM-Lower Mahaweli).

The surface and the bottom sediments of the Kuma River have the same composition (Figure 5b). The provenance of Yatsushiro Bay was examined using sediment elementary data of 2006, 2012 and 2013 (Young and Ishiga, 2014a). The Yatsushiro Bay sediment data shows that there is a change in composition since 2006-2013 (Figure 5c). The Yatsushiro Bay sediment composition with time have moved towards the composition of PAAS from 2006-2012. After 2012 the composition moves toward the line on Rhyolite to Dacite up to 2013 with not much change (Figure 5c). Thus, in the Yatsushiro Bay the composition changes to the background detrital composition (Young and Ishiga, 2014a).

\section{Environmental conditions of river systems in Sri Lanka and Japan}

The elements $\mathrm{Y}, \mathrm{Th}, \mathrm{Zr}, \mathrm{Nb}, \mathrm{Ti}$ and $\mathrm{Sc}$ are good indicators of heavy minerals. Owing to high durability, minerals tend to remain in sediments during transport over long distances. Tourmaline, zircon, and rutile are associated with significant enrichments of $\mathrm{Th}, \mathrm{Zr}$ and $\mathrm{Nb}$, and suggest a granitic source or recycled detritus (Young et al., 2013).

Disseminations of $\mathrm{Th}, \mathrm{Zr}$ and $\mathrm{Nb}$ in the stream sediments are usually controlled by heavy minerals including garnet, monazite, zircon and titanite, with the lesser changeability being produced by homogenization of the detrital bedload during transport. The scattering of $\mathrm{Zr}$ to higher values is comparatively rational, this suggests that the zircon concentration is the main reason for enrichment (Young et al., 2013). It is suggested that the higher scattering of $\mathrm{Y}$ and $\mathrm{Nb}$ is controlled by the abundance of multiple heavy minerals. The sediments of the tributaries also show high values for $\mathrm{Th}, \mathrm{Zr}$ and $\mathrm{Nb}$ in the $<180 \mu \mathrm{m}$ fraction, suggesting that preferential concentration of heavy minerals in the fine fraction is not a function of transport distance (Young et al., 2013). Spikes at the entries of tributaries are likely to be caused by heavy minerals, and there is no significant change seen with climatic zones (Young et al., 2013).

The LOI values of the soils are 0.61-12.86 wt $\%$ and sediments range between 0.31-16.18 wt $\%$, indicating considerable amounts of organic matter in the sediments. However, Calcium contents are naturally high in the carbonate rocks in the Mahaweli River catchment. Since the Ca contents are high, for weathering interpretations in the Mahaweli River, the CIA, PIA, CIW, and WIP indexes cannot be used. Nevertheless, the ratios of immobile to mobile elements $\left(\mathrm{K}_{2} \mathrm{O} / \mathrm{Na}_{2} \mathrm{O}\right.$ and $\left.\mathrm{Al}_{2} \mathrm{O}_{3} /\left(\mathrm{K}_{2} \mathrm{O}+\mathrm{Na}_{2} \mathrm{O}\right)\right)$ can be used to determine the degree of weathering and morbidity (Nesbitt and Young, 1982; Gallet et al., 1996) and was used for the Mahaweli River to determine the weathering across the three climatic zones. A clear 8 
change across the climatic zones for the $\mathrm{Al}_{2} \mathrm{O}_{3} /\left(\mathrm{K}_{2} \mathrm{O}+\mathrm{Na}_{2} \mathrm{O}\right)$ ratios (Young et al., 2013). Due to the rich $\mathrm{Al}$ content in the wet zone sediments, it can be implied that considerable amount of clay is derived from feldspars. It also shows that intense weathering occurs in the elevated areas of the upper catchment and decreases downstream (Young et al., 2013).

The Enrichment Factor (EF) is commonly used to detect the anthropogenic signatures. For the Mahaweli River sediments all other elements are strongly depleted, with $\mathrm{EF}<1$ except for $\mathrm{Cr}$ throughout the river and $\mathrm{Pb}$ at a few sites in the dry zone and may related to the local lithology. Thus, Mahaweli River sediments represent background values, and there is no threat of anthropogenic contamination (Sutherland, 2000; Zhang and Liu, 2002).

The EF of the sediments of the Kuma River is less than 1.5 for all elements (Young and Ishiga, 2014b) indicating that there is no anthropogenic contamination as for Zhang et al., 2007 and the Yathsushiro Bay sediments EF are similar to the Kuma River sediments (Young and Ishiga, 2014b). The Kuma River sediments consists of low LOI values (2.32-2.99) indicating less organic matter in the sediments. However, location YA-1 has a LOI of 18.10 which is very high and the southern area of the Uto Peninsula area consists of a high value of LOI (8.27-11.02) and indicates high organic matter content in the sediments (Young and Ishiga, 2014a).

\section{Conclusions}

When consider both river systems, the mass transfer process and their potential impacts on the terrestrial and marine environments could be related to provenance, maturity of sediments, weathering, climatic Implications, sedimentary processes, heavy minerals concentration, sorting and mixing effect, grain size, transport and downstream accumulation, effect of tributaries and sediment recycling.

The main processes involved in the Mahaweli River and Trincomalee Bay sediment environments are; transport, sorting, erosion, weathering, deposition, heavy minerals, tributary input and climate. The Kuma River and Yatsushiro Bay involves erosion, deposition, sorting and transport.

\section{Acknowledgment}

Author acknowledge the Japanese government for financial assistance to carry out our study, the staff of Shimane University for the unending support for analysis and guidance.

\section{References}

Fedo, C.M., Nesbitt, H.W. and Young, G.M., 1995. Unraveling the effects of potassium metasomatism in sedimentary rocks and paleosols, with implications for paleo weathering conditions and provenance. Geology, 23: 921-924.

Folk, R.L. and Ward, W.C., 1957. Brazos river bar: a study of significance of grain size parameters. Journal of Sedimentary Petrology, 27:3-26.

Gallet, S., Jahn, B.M. and Torii, M., 1996. Geochemical characterization of the Luochuan loess-paleosol sequence, China and paleoclimatic implications. Chemical Geology, 133:67-88.

Harnois, L., 1988. The CIW index: A new chemical index of weathering. Sedimentary Geology, 55:319322.

Ishiga, H., Sakaya, M., Sakamoto, M., Hasegawa, M., Young, S.M. and Diallo, I.M., 2012. Geochemical evaluation of the effect on a tidal flat environment by fluvial flooding in the Miyagawwa River mouth estuary, Ise area, Mie prefecture Japan. Geoscience Reports of Shimane University, 31:5969.

Johnsson, M.J., 1993. The system controlling the composition of clastic sediments. Geological Society of America Special Paper, 284:1-19. 
McLennan, S.M., Hemming, S., McDaniel, D.K. and Hanson, G.N., 1993. Geochemical approaches to sedimentation, provenance and tectonics. The Geological Society of America. Special Paper, 284:21-40.

Nagarajan, R., Madhavaraju, J., Nagendra, R., Armstrong-Altrin, J.S. and Moutte, J., 2007. Geochemistry of Neoproterozoic shales of the Rabanpalli formation, Bhima basin, northern Karnataka, southern India: implications for provenance and paleoredox conditions. Revista Mexicana de Ciencias Geologicas, 24:150-160.

Nesbitt, H.W. and Young, G.M., 1982. Early Proterozoic climates and plate motions inferred from major element chemistry of lutites. Nature, 299:715-717.

NYSDEC (New York State Department of Environmental Conservation) 1999. Technical guidance for screening contaminated sediments (45). Albany, NY:NYSDEC, Division of Fish, Wildlife and Marine Resources.

Ogasawara, M., 1987. Trace element analysis of rock samples by X-ray fluorescence spectrometry, using Rh anode tube. Bulletin of Geological Survey of Japan, 38: 57-68.

Ogawa, Y., Nishiyama, T., Obata, M., Nishi, T., Miyazaki, K., Ikeda, T., Yoshimura, Y. and Nagakawa, K., 1992. Continental margin tectonics in Kyushu, southwest Japan-Mesozoic paired metamorphic belts and accretionary complexes. Paleozoic and Mesozoic terranes: basement of the Japanese island arcs. 29 $9^{\text {th }}$ IGC field trip guide book Vol.1. Nagoya University, 1:261-315.

Ohta, T. and Arai, H., 2007. Statistical empirical index of chemical weathering in igneous rocks: A new tool for evaluating the degree of weathering. Chemical Geology, 240:280-297.

Ottesen, R.T. and Theobald, P.K., 1994. Stream sediments in mineral exploration. In Hale M. and Plant J. A. (eds). Handbook of Exploration Geochemistry, Elsevier, Amsterdam, 6:147-84.

Parker, G., 1991. Downstream variation of grain size in gravel rivers: Abrasion versus selective sorting. Fluvial hydraulics of mountain regions, Springer, Berlin, Heidelberg, 37:345-360.

Qingjie, G., Jun, D., Yunchuan, X., Qingfei, W. and Liqiang, Y., 2008. Calculating pollution indices by heavy metals in ecological geochemistry assessment and a case study in parks of Beijing, Journal of China University of Geosciences, 19:230-241.

Roser, B.P., Ishiga, H. and Lee, H.K., 2000. Geochemistry and provenance of Cretaceous sediments from the Euisong block, Gyeongsang Basin, Korea, Mem. Geol. Soc. Japan, 57, 155-170.

Roser, B.P. and Korsch, R.J., 1999. Geochemical characterization, evolution and source of a Mesozoic accretionary wedge: The Torlesse terrane, New Zealand, Geol. Mag. Cambridge University Press 136:493-512.

Sakai, T., Okada, H. and Aihara, A., 1992. Cretaceous and Tertiary active margin sedimentation: transect of Kyushu. Paleozoic and Mesozoic terranes: basement of the Japanese island arcs. $29^{\text {th }}$ IGC field trip guide book Vol.1. Nagoya University, 1:317-354.

Surian, N., 2002. Downstream variation in grain size along an Alpine river: analysis of controls and processes. Geomorphology, 43:137-149.

Sutherland, R.A., 2000. A comparison of geochemical information obtained from two fluvial bed sediment fractions. Environmental Geology, 39:330-341.

Taylor, S.R. and McLennan, S.M., 1985. The continental crust: its composition and evolution. Oxford: Blackwell Scientific. 312.

Woods, A.M., Lloyd, J.M., Zong, Y. and Brodie, C.R., 2012. Spatial mapping of Pearl River Estuary surface sediment geochemistry: Influence of data analysis on environmental interpretation, Estuarine, Coastal and Shelf Science, 115, 218-233.

Young, S.M., Pitawala, A. and Ishiga, H., 2013. Geochemical characteristics of stream sediments, sediment fractions, soils, and basement rocks from the Mahaweli River and its catchment, Sri Lanka. Chemie der Erde, 73: 357-371. 
Young, S.M., Ishiga, H., Roser, B.P. and Pitawala, A., 2014. Geochemistry of sediments in three sectors of Trincomalee Bay, Sri Lanka: Provenance, modifying factors, and present environmental status. Journal of Soils and Sediments. Journal of Soils and Sediments, 14:204-217.

Young S.M. and Ishiga, H., 2014a. Environmental change of the fluvial-estuary system in relation to Arase dam removal of the Yatsushiro tidal flat, SW Kyushu, Japan. Environmental Earth Sciences

Young, S.M. and Ishiga, H., 2014b. Assessment of dam removal from geochemical examination of Kuma River, Kyushu, Japan. Environmental Monitoring and Assessment. 186:8267-8289.

Zhang, L., Ye, X., Feng, H., Jing, Y., Ouyang, T., Yu, X., Liang, R., Gao, C. and Chen, W., 2007. Heavy metal contamination in western Xiamen Bay sediments and its vicinity, China. Marine Pollution Bulletin, 54:974-982.

Zhang, J. and Liu, C.L., 2002. Riverine composition and estuarine geochemistry of particulate metals in China-weathering features, Anthropogenic Impact and Chemical Fluxes. Estuarine, Coastal and Shelf Science, 54:1051-1070. 